
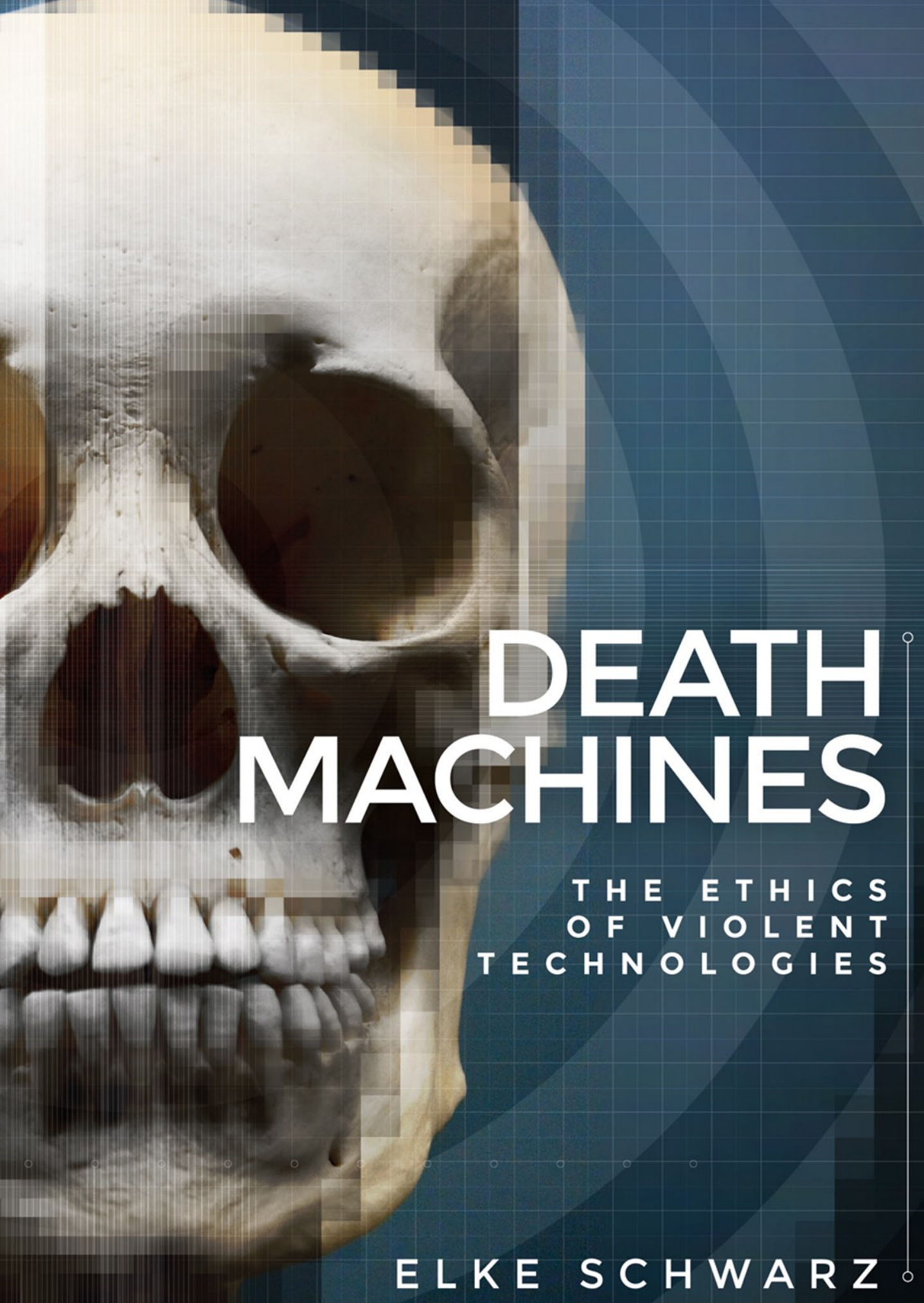

$$
\text { ELKE SCHWARZ。 }
$$




\section{Death machines}

\section{MANCHESTER 1824}

Manchester University Press 
Elke Schwarz - 9781526114839 Downloaded from manchesterhive.com at 04/26/2023 12:45:24PM via free access 


\title{
Death machines
}

\section{The ethics of violent technologies}

\author{
Elke Schwarz
}

Manchester University Press 
The right of Elke Schwarz to be identified as the author of this work has been asserted by her in accordance with the Copyright, Designs and Patents Act 1988.

\author{
Published by Manchester University Press \\ Altrincham Street, Manchester M1 7JA \\ www.manchesteruniversitypress.co.uk \\ British Library Cataloguing-in-Publication Data \\ A catalogue record for this book is available from the British Library
}

ISBN $978 \quad 1 \quad 5261 \quad 1482 \quad 2$ hardback

First published 2018

The publisher has no responsibility for the persistence or accuracy of URLs for any external or third-party internet websites referred to in this book, and does not guarantee that any content on such websites is, or will remain, accurate or appropriate.

Typeset

by Toppan Best-set Premedia Limited 